\title{
РЕМОДЕЛЮВАННЯ СЕРЦЯ В ЩУРІВ В УМОВАХ РОЗВИТКУ МЕТАБОЛІЧНОЇ КАРДІОМІОПАТІЇ ТА МОЖЛИВОСТІ ЙОГО КОРЕКЦІї
}

\author{
๑В. Є. Пелих, Г. С. Сатурська, Р. С. Усинський \\ Тернопільський начіональний медичний університет імені І. Я. Горбачевського МОЗ України
}

РЕзЮМЕ. Протизапальна та імуносупресивна терапія часто включає застосування глюкокортикостероїдів, проте тривале їх використання, переважно при лікуванні хронічних захворювань, часто призводить до несприятливих та серйозних побічних наслідків. Одним із них $€$ метаболічна кардіоміопатія. 3 іншого боку, амінокислота L-карнітин має важливу властивість, зокрема, сприяє транспортуванню ліпідів усередину мітохондрій. На експериментальній стероїдній кардіоміопатії було доведено, що L-карнітин запобігає розвитку масометричної перебудови (ремоделюванню) серця, знижуючи катаболічну дію дексаметазону, і таким чином дозволяє нормалізувати загальну масу тіла та, зокрема, абсолютну масу лівого і правого шлуночків серця, пошкодженого дексаметазоном.

Мета роботи - визначити можливість запобігання розвитку структурно-дистрофічних змін міокарда щурів різної статі внаслідок тривалого застосування кортикостероїдів.

Матеріал і методи. Експерименти були проведені на 48 дорослих білих безпородних щурах різної статі, які були поділені на 4 групи. У ході дослідження вимірювали масу тіла тварини та абсолютну масу лівого і правого шлуночків серця (морфометрія).

Висновки. L-карнітин (у дозі 200 мг/кг ваги тварини рег os) здатний знижувати катаболічну дію дексаметазону (у дозі 350 мкг/кг маси тіла тварини рег os) і в такий спосіб нормалізувати масу тіла та абсолютну вагу лівого і правого шлуночків серця. В умовах експериментальної кортикостероїдної кардіоміопатії L-карнітин запобігає розвитку масометричної перебудови (ремоделюванню) серця. Перспективним $\epsilon$ вивчення структурно-дегенеративних змін серця на підставі визначення співвідношення мас / об'ємів кардіоміоцитів до сполучної тканини.

КлючОВІ СлОВА: кардіоміопатія; дексаметазон; L-карнітин; морфометрія.

Вступ. Глюкокортикоїди широко застосовуються у практичній медицині як протизапальні та імунодепресивні засоби [1], проте тривале їх використання, переважно при лікуванні хронічних захворювань, часто призводить до несприятливих та серйозних побічних наслідків, включаючи синдром Кушинга, остеопороз, шлунково-кишкові кровотечі та дисліпідемію [1]. Відомо, що підвищений рівень як ендогенних $[2,3]$, так і екзогенних $[4,5]$ глюкокортикоїдів сприяє виникненню метаболічного синдрому, включаючи інсулінорезистентність, ожиріння, артеріальну гіпертензію, розвитку дистрофічних змін кардіоміоцитів. Як відомо, серце отримує більшу частину енергії за рахунок метаболізму глюкози та жирних кислот. Після поглинання глюкози та її гліколізу піруватдегідрогеназний комплекс полегшує потрапляння пірувату в мітохондрії, а зміни ії активності змінюють процеси утилізації глюкози. Таким чином, дефосфорилювання за допомогою піруватдегідрогенази-фосфатази активує, тоді як фосфорилювання за допомогою піруватдегідрогенази-кінази інактивує піруватдегідрогеназний комплекс, у результаті чого відповідно збільшується або інгібується окиснення глюкози. Порівняно з глюкозою, жирні кислоти $\epsilon$ кращим субстратом для забезпечення енергією серцевого м'яза [6]. 3 гідролізом жирних кислот, зокрема, багатих на тригліцериди форм ліпопротеїдів ліпопротеїн-ліпазою, яка розташована на поверхні ендотелію коронарних судин, асимілюється важливе джерело енергії для забезпечення потреб серця [7]. Ендотеліальні клітини самостійно не синтезують ліпопротеїн-ліпазу, а значить, фермент синтезується в кардіоміоцитах. Регулювання кількості ліпопротеїн-ліпази у просвіті судин $\epsilon$ одним із важливих механізмів, завдяки якому серце здатне підтримувати свою функцію під час метаболічного стресу. На сьогоднішній день існує цілий клас препаратів метаболічної дії, серед яких і амінокислота L-карнітин, які уже застосовують, наприклад, для лікування IXC. Такі препарати $\epsilon$ перспективними з точки зору лікування чи навіть профілактики і метаболічної кардіоміопатії різного ґенезу.

Метаболічні кардіоміопатії розвиваються в умовах широкого спектра патологічних станів. До них належать ряд спадкових захворювань обміну речовин у ранньому дитинстві, при цьому страждає не тільки серце, а й інші органи [3, 5]. Кардіоміопатія часто виникає як наслідок порушення вироблення енергії, пов'язаного з дефектами метаболізму глікогену, ліпідів та мукополісахаридів. Інший патогенетичний шлях виникнення кардіоміопатій пов'язаний із системними метаболічними захворюваннями, набутими в зрілому віці, такими як цукровий діабет та інші. На ранній стадії метаболічної кардіоміопатії порушення обміну речовин не супроводжується істотними змінами структури міокарда та його функції. Однак порушення метаболізму викликає субклітинне запалення в серці, субклітинні порушення, зокрема ендоплазматичного ретикулуму, з розвитком окис- 
Огляди літератури, оригінальні дослідження, погляд на проблему, випадок з практики, короткі повідомлення нювального стресу, мітохондріальної дисфункції, порушення кальцієвого току через мембрану, що, у свою чергу, призводить до порушення розслаблення міокарда [5]. На запущеній стадії замкнуті кола порушень субклітинних процесів, запальна клітинна інфільтрація та нейрогуморальна активація викликають ушкодження та смерть кардіоміоцитів, серцевий фіброз, що призводить до порушення як діастолічної, так і систолічної функцій. Механізм дії L-карнітину пов'язують саме із його метаболічною функцією у клітині, - він сприяє переносу жирних кислот у мітохондрії (які стають субстратом для утворення АТФ), що, у свою чергу, попереджає їх нагромадження у цитоплазмі і відповідно запуск одного з ключових механізмів пошкодження клітини - ліпідного (детергентна дія надлишку вільних жирних кислот). Враховуючи наведені позитивні метаболічні ефекти його, ми поставили за мету наших досліджень вивчити можливості запобігання ремоделюванню пошкодженого глюкокортикоїдами серця щурів різної статі.

Мета - визначення зміни маси тіла, лівого та правого шлуночків серця тварин різної статі, пошкодженого глюкокортикоїдами, та виявлення можливості запобігання їм за допомогою L-карнітину.

Матеріал і методи дослідження. Досліди провели на 48 статевозрілих самках та самцях нелінійних білих щурів масою 0,19-0,27 кг з дотриманням норм біоетики Європейської конвенції захисту хребетних тварин [8]. Експериментальну стероїдну кардіоміопатію як клінічний прояв метаболічної моделювали шляхом введення рег os 0,035 \% розчину дексаметазону в дозі 350 мкг/кг маси тварини протягом 15 днів [9]. 3 метою запобігання пошкодженню серця в процесі розвитку кардіоміопатії використовували L-карнітин (препарат «Агвантар", р-н оральний 20 \%, Ерсель Фарма) який за 4 дні до початку введення дексаметазону починали вводити тваринам рег os в дозі 200 мг/кг маси протягом 19 днів [10]. Визначали масу тварин

(мт), масометричні показники серця щурів різної статі за методикою Г. Г. Автанділова [11] (зважування частин серця проводили за W. Mulleг у модифікації Г. І. Ільїна). Зокрема, визначали абсолютну масу лівого (амЛШ) та правого (амПШ) шлуночків (маса шлуночка з пропорційною йому масою міжшлуночкової перегородки). Достовірність отриманих відмінностей між результатами (мінімальний рівень значущості $p \leq 0,05)$ визначали за допомогою критерію Ньюмена-Кейлса (програма StatPlus версія 6 (додаток StatFi для Microsoft Excel), AnalystSoft Inc.).

Результати й обговорення. Аналізуючи зміни маси тіла контрольних тварин обох статей, що отримували L-карнітин в якості контролю на препарат, виявили, що в кінцевому результаті в самців вона була вищою на $41,7 \%(p<0,01)$, ніж у самок (табл. 1). При цьому застосування L-карнітину протягом 15-ти днів спричинило зниження маси тіла у самок на $21,7 \%(p<0,02)$, у самців на $17,2 \%$ $(p<0,02)$, тобто при цьому залишилась різниця між особинами різної статі, зокрема у самок досліджуваний показник був менший на $50 \%$ $(p<0,001)$. Враховуючи той факт, що L-карнітин вiдіграє важливу роль у транспорті жирних кислот через мембрани мітохондрій і включенні їх у процес окиснення для забезпечення енергією власне клітини, зниження маси тіла щурів можна пояснити посиленим залученням жирів із жирової клітковини. Цей процес стає тим активнішим, чим більша потреба клітин в енергії, наприклад, у фізіологічних умовах - фізичне навантаження, чи патологічні стани, пов'язані з активацією метаболізму. Позитивним моментом у даному випадку $\epsilon$ те, що утворення АТФ шляхом окиснення жирних кислот потребує значно менше молекул кисню, ніж, наприклад, глюкози. В умовах патології, що супроводжується гіпоксією, такі метаболічні перебудови сприяють меншому пошкодженню клітин (такі ефекти притаманні препаратам з метаболічною дією і використовуються у кардіології при лікуванні IXC).

Таблиця 1. Зміни маси тіла досліджуваних тварин за умови застосування дексаметазону та L-карнітину $(X \pm \sigma), \mathrm{n}=12$

\begin{tabular}{|c|c|c|c|c|}
\hline Група тварин & $\begin{array}{c}1 \text { група } \\
\text { Контроль }\end{array}$ & $\begin{array}{c}2 \text { група } \\
\text { L-карнітин }\end{array}$ & $\begin{array}{c}3 \text { група } \\
\text { Дексаметазон }\end{array}$ & $\begin{array}{c}4 \text { група } \\
\text { Дексаметазон +L-карнітин }\end{array}$ \\
\hline Самки 9 & $192 \pm 31$ & $150 \pm 22 *$ & $113 \pm 20 *$ & $147 \pm 37 *$ \\
\hline Самці ${ }^{\star}$ & $272 \pm 40 \#$ & $225 \pm 15^{*} \#$ & $158 \pm 34 * \#$ & $258 \pm 32 * \#$ \\
\hline
\end{tabular}

Примітка. * - достовірна різниця в порівнянні з тваринами 1 групи $(p<0,05)$; \# - достовірна різниця між показниками тварин різної статі $(p<0,05)$.

Підтвердженням катаболічних властивостей тривалого застосування дексаметазону було достовірне зниження маси тіла у тварин обох статей в 1,7 раза $(p<0,001)$. При цьому в самок маса тіла була на 39,7 \% ( $p=0,01)$ менша, порівняно з самцями. При застосуванні L-карнітину з протекторною метою у тварин, що отримували дексаметазон, маса тіла збільшилась на 29,4 \% (p=0,04) та 63,2 \% 
Огляди літератури, оригінальні дослідження, погляд на проблему, випадок з практики, короткі повідомлення ( $<<0,001)$ відповідно в самок та самців. Профілактичне застосування препарату виявилась досить ефективним у збереженні маси тіла. При цьому в самців середня маса тіла достовірно не відрізнялась від групи контрольних тварин. У самок повного відновлення досліджуваного показника не вдалось досягти - маса тіла у даних тварин достовірно була нижчою на 23,5\% (p=0,01) від рівня контрольної групи.

При аналізі змін абсолютної маси лівого шлуночка (амЛШ) було виявлено, що у самців цей показник на всіх етапах експерименту достовірно був вищим, ніж у самок, зокрема, у контрольних тварин - на 47,1 \% (р<0,01) (рис. 1), при застосуванні L-карнітину - на 69,4\% ( $<<0,001)$, у тварин 3 кардіоміопатією - на 76,8 \% ( $p<0,001)$, з кардіоміопатією, коригованою L-карнітином - на 65,6 \% $(p<0,001)$.

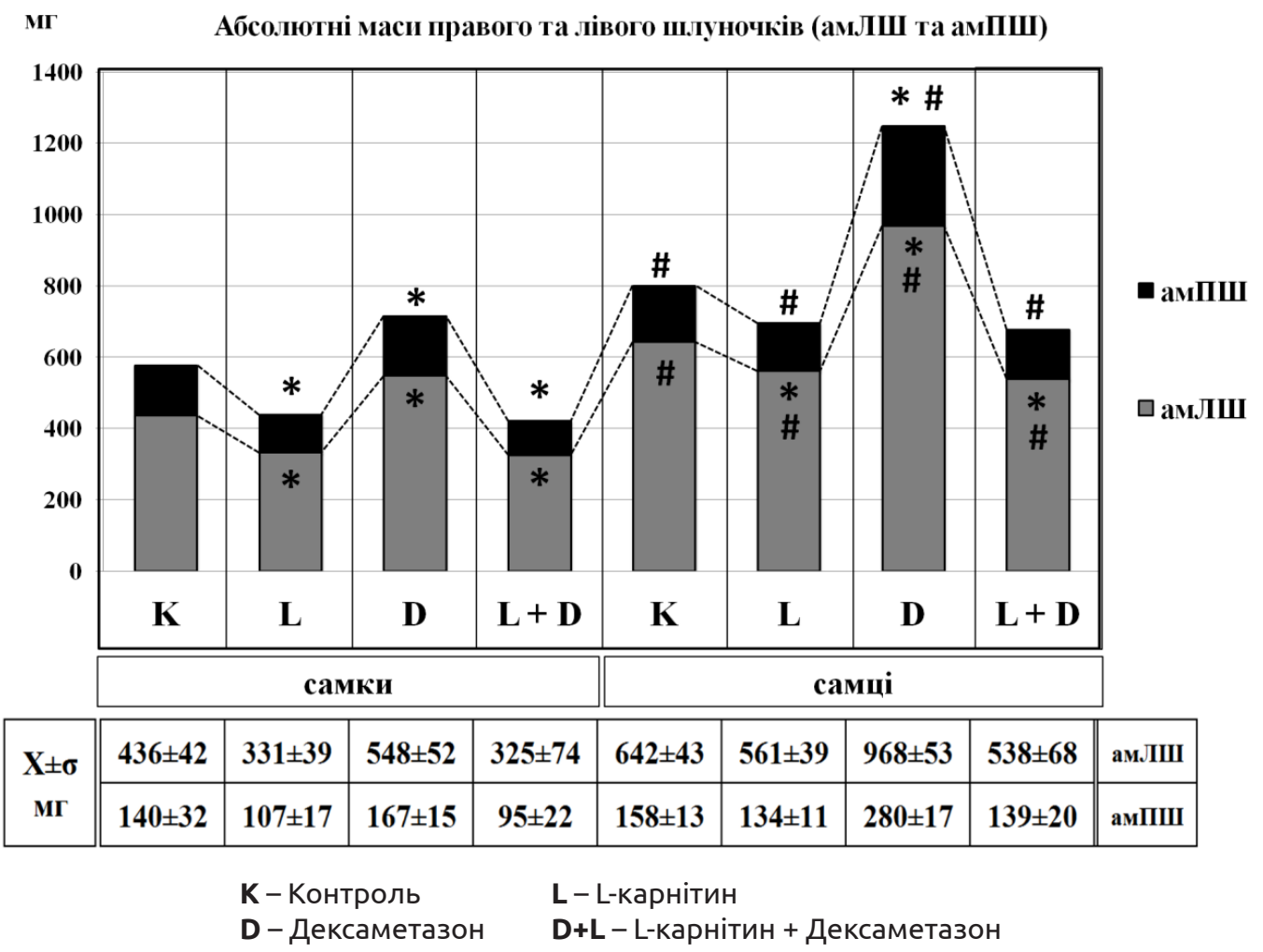

Примітка: * - достовірна різниця в порівнянні з тваринами контрольної групи $(p<0,05)$;

\# - достовірна різниця показника тварин різної статі $(p<0,05)$.

Рис. 1. Динаміка абсолютної маси лівого та правого шлуночків серця в процесі розвитку стероїдної кардіоміопатії та застосуванні L-карнітину.

L-карнітин сприяв зниженню абсолютної маси лівого шлуночка на 24,1 \% $(p<0,01)$ у самок та на $12,6 \%(p<0,01)$ у самців, відносно інтактних тварин). Розвиток стероїдної кардіоміопатії внаслідок тривалого застосування дексаметазону супроводжувався підвищенням досліджуваного показника у самок на 25,5 \% (р<0,01), а у самців на 50,8 \% ( $<<0,001)$. У тварин, що отримували дексаметазон, L-карнітин в якості протектора сприяв зниженню абсолютної маси лівого шлуночка на 40,7 \% $(p<0,01)$ у самок та на $44,5 \%(p<0,001)$ у самців, що було менше, ніж у контрольній групі, відповідно на $25,6 \%(p<0,01)$ та 16,2\% (p<0,01).

Правий шлуночок (його абсолютна маса, амПШ), згідно з даними морфометрії, на етапах моделювання кардіоміопатії, за винятком конт- рольних тварин, також виявився більшим у самців, порівняно із самками, за умови дії лише L-карнітину (на 25 \%; р<0,01), дексаметазону (на 67,2; p<0,001) та при поєднанні дексаметазону та L-карнітину (на 45,8 \%; p<0,001). У самок щурів, які отримували L-карнітин, досліджуваний показник зменшився на 23,7 \% ( $<<0,01)$, у самців зміни були не достовірні. На 15-ий день розвитку кардіоміопатії, індукованої застосуванням дексаметазону, абсолютна маса правого шлуночка збільшилась у самок на $19,3(p<0,01)$, а у самців на $77,2 \%$ $(p<0,01)$. У тварин, що отримували дексаметазон, L-карнітин в якості кардіопротектора сприяв зниженню досліджуваного показника у самок на $43,1 \%(p<0,01)$, у самців на 50,4\% ( $<<0,01)$, що у самок на $32,1 \%(p<0,01)$ було нижче від рівня 
Огляди літератури, оригінальні дослідження, погляд на проблему, випадок з практики, короткі повідомлення контролю, натомість у самців достовірно не відрізнялось.

Висновки. L-карнітин (у дозі 200 мг/кг ваги тварини рег os) здатний знижувати катаболічну дію дексаметазону (у дозі 350 мкг/кг маси тіла тварини рег os) і в такий спосіб нормалізувати масу тіла та абсолютну вагу лівого і правого шлу-

ночків серця. В умовах експериментальної кортикостероїдної кардіоміопатії L-карнітин запобігає розвитку масометричної перебудови (ремоделюванню) серця. Перспективним $є$ вивчення структурно-дегенеративних змін серця на підставі визначення співвідношення мас/об'ємів кардіоміоцитів до сполучної тканини.

\section{ЛІТЕРАТУРА}

1. Alan I. S. Effects of glucocorticoids / I. S. Alan, B. Alan // Pharmacokinetics and Adverse Effects of Drugs Mechanisms and Risks Factors. - 2018. - P. 93-115.

2. Endothelial glucocorticoid receptor suppresses atherogenesis / J. E. Goodwin, X. Zhang, N. Rotllan [et al.] // Brief Report. Arteriosclerosis, Thrombosis, and Vascular Biology. - 2015. - Vol. 35, No. 4. - P. 779-782.

3. Gupta Y. Glucocorticoid-induced myopathy: Pathophysiology, diagnosis, and treatment / Y. Gupta, A. Gupta // Indian Journal of Endocrinology and Metabolism. 2013. - Vol. 17, No. 5. - P. 913-925.

4. The glucocorticoid receptor in cardiovascular health and disease / Liu, Zhang, Knight [et al.] // Cells. 2019. - Vol. 8, No. 10. - P. 1227-1149.

5. Nishida K. Inflammation and metabolic cardiomyopathy / K. Nishida, K. Otsu // Cardiovascular Research. 2017. - Vol. 113, No. 4. - P. 389-398.

6. Dual role for glucocorticoids in cardiomyocyte hypertrophy and apoptosis / R. Ren, R. H. Oakley, D. Cruz-

\section{REFERENCES}

1. Alan, I. S., \& Alan, B. (2018). Side effects of glucocorticoids. Pharmacokinetics and Adverse Effects of Drugs Mechanisms and Risks Factors, 93-115. DOI:10.5772/intechopen.72019.

2. Goodwin, J.E., Zhang, X., Rotllan, N., Feng, Y., Zhou, H., Fernández-Hernando, C., Sessa, W.C. (2015). Endothelial glucocorticoid receptor suppresses atherogenesis - brief report. Arteriosclerosis, Thrombosis, and Vascular Biology, 35 (4), 779-782. DOI:10.1161/atvbaha.114.304525.

3. Gupta, Y., \& Gupta, A. (2013). Glucocorticoid-induced myopathy: Pathophysiology, diagnosis, and treatment. Indian Journal of Endocrinology and Metabolism, 17 (5), 913-925. DOI:10.4103/2230-8210.117215.

4. Liu, Zhang, Knight, \& Goodwin (2019). The glucocorticoid receptor in cardiovascular health and disease. Cells, 8 (10), 1227-1149. DOI:10.3390/cells8101227.

5. Nishida, K., \& Otsu, K. (2017). Inflammation and metabolic cardiomyopathy. Cardiovascular Research, 113 (4), 389-398. DOI:10.1093/cvr/cvx012

6. Ren, R., Oakley, R.H., Cruz-Topete, D., \& Cidlowski, J.A. (2012). Dual role for glucocorticoids in cardiomyo-

Topete [et al.] // Endocrinology. - 2012. - Vol. 153, No. 11. P. 5346-5360.

7. Single-dose dexamethasone induces whole-body insulin resistance and alters both cardiac fatty acid and carbohydrate metabolism / D. Qi, T. Pulinilkunnil, D. An, [et al.] // Diabetes. - 2004. - Vol. 53, No. 7. - P. 1790-1797.

8. European convention for the protection of vertebrate animals used for experimental and other scientific purposes. - Council of Europe, Strasbourg. - 1986. - 53 p.

9. Kopple J. D. L-carnitine ameliorates gentamicin-induced renal injury in rats / J. D. Kopple // Nephrology Dialysis Transplantation. - 2002. - Vol. 17, No. 12. - P. 2122-2131.

10. Excess of glucocorticoid induces cardiac dysfunction via activating angiotensin II pathway / S. G. Roy, P. De, D. Mukherjee [et al.] / Cellular Physiology and Biochemistry. - 2009. - Vol. 24, No. 1-2. - P. 1-10.

11. Автандилов Г. Г. Основы количественной патологической анатомии / Г. Г. Автандилов. - М. : Медицина, 2002. -240 c. cyte hypertrophy and apoptosis. Endocrinology, 153 (11), 5346-5360. DOI:10.1210/en.2012-1563

7. Qi, D., Pulinilkunnil, T., An, D., Ghosh, S., Abrahani, A., Pospisilik, J.A., \& Rodrigues, B. (2004). Single-dose dexamethasone induces whole-body insulin resistance and alters both cardiac fatty acid and carbohydrate metabolism. Diabetes, 53 (7), 1790-1797. DOI:10.2337/diabetes.53.7.1790

8. European convention for the protection of vertebrate animals used for experimental and other scientific purposes. (1986). Strasbourg: Council of Europe.

9. Kopple, J.D. (2002). L-carnitine ameliorates gentamicin-induced renal injury in rats. Nephrology Dialysis Transplantation,17 (12), 2122-2131.

10. Roy, S.G., De, P., Mukherjee, D., Chander, V., Konar, A., Bandyopadhyay, D., \& Bandyopadhyay, A. (2009). Excess of glucocorticoid induces cardiac dysfunction via activating angiotensin II pathway. Cellular Physiology and Biochemistry, 24 (1-2), 1-10.

11. Avtandilov, G.G. (2002). Osnovy kolichestvennoy patologicheskoy anatomii [Bases of quantitative pathological anatomy]. Moscow: Meditsina [in Russian]. 

КАРДИОМИОПАТИИ И ВОЗМОЖНОСТИ ЕГО КОРРЕКЦИИ

\author{
○В. Е. Пелих, Г. С. Сатурская, Р. С. Усинський
}

Тернопольский национальный медицинский университет имени И. Я. Горбачевского МОз Украины

РЕЗЮМЕ. Противовоспалительная и иммуносупрессивная терапия часто включает использование глюкокортикостероидов, однако длительное использование их, преимущественно при лечении хронических заболеваний, часто приводит к неблагоприятным и побочным осложнениям. Одним из них является метаболическая кардиомиопатия. С другой стороны, аминокислота L-карнитин имеет важное свойство, в частности, способствует транспорту липидов внутрь митохондрий. В экспериментальной модели стероидной кардиомиопатии было доказано, что L-карнитин предупреждает развитие массометрической перестройки (ремоделирования) сердца, снижая катаболическое действие дексаметазона, и таким образом нормализует общую массу тела и, в частности, абсолютную массу левого и правого желудочков сердца, поврежденного дексаметазоном.

Цель - определить возможность предупреждения развития структурно-дистрофических изменений миокарда крыс разного пола вследствие длительного применения кортикостероидов.

Материал и методы. Эксперименты были проведены на 48 взрослых белых беспородных крысах разного пола, которые были поделены на 4 группы. В нашем эксперименте мы измеряли вес животного, абсолютную массу левого и правого желудочков сердца (морфометрия).

Выводы. L-карнитин (в дозе 200 мг/кг веса животного рег os) обладает способностью значительно снижать катаболическое действие дексаметазона (в дозе 350 мкг/кг массы тела животного рег os) и таким образом нормализовать общую массу тела и абсолютную массу левого и правого желудочков сердца. В условиях экспериментальной кортикостероидной кардиомиопатии L-карнитин предупреждает развитие массометрической перестройки (ремоделирование) сердца. Перспективным является изучение структурно-дегенеративных изменений на основе определения соотношения масс/объемов кардиомиоцитов к соединительной ткани.

КЛЮЧЕВЫЕ СЛОВА: кардиомиопатия; дексаметазон; L-карнитин; морфометрия.

\title{
REMODELING OF RAT'S HEART IN CONDITIONS OF METABOLIC CARDIOMYOPATHY DEVELOPMENT AND POSSIBILITIES OF ITS CORRECTION
}

\author{
○V. Ye. Pelykh, H. S. Saturska, R. S. Usynskyi \\ I. Horbachevsky Ternopil National Medical University
}

SUMMARY. Anti-inflammatory and immunosuppressive therapy often includes using glucocorticosteroids, but after long-term their use for treatment of chronic diseases especially often arise unfavorable and secondary complications. One of them is metabolic cardiomyopathy. On the other hand, aminoacid L-carnitine has important property in particular it promotes to transport lipids inside mitochondria. In the experimental model of steroid cardiomyopathy was demonstrated that L-carnitine preventes development of heart massometric remodeling reducing catabolic action of the dexamethasone thus normalizes total weight body and in particular absolute weight of the left and the right ventricle of the heart, damaged by dexamethasone.

The aim - to determinate the possibility of prevention of structural dystrophic changes development in the rat's heart of different sex owing to long-term use corticosteroids.

Material and Methods. Experiments were performed on 48 adult white rats of different sex, which were divided into 4 groups. The total weight of animal, absolute weight of left and right ventricles of heart were measured (morphometry) in the experiment.

Conclusions. L-carnitine (in dose $200 \mathrm{mg} / \mathrm{kg}$ of animal weight per os) has the ability to significantly reduce the catabolic effects of dexamethasone and thus normalization of body weight and absolute weight of the left and right ventricles of heart. That L-carnitine (in dose $350 \mu \mathrm{g} / \mathrm{kg}$ of animal body weight per os) is able to prevent massometric remodeling of the heart in modelled cardiomyopathy. The studing of structural-degenerative changes on the base determination of the ratio masses/volumes of cardiomyocytes to connective tissue it is perspective.

KEY WORDS: cardiomyopathy; dexamethasone; L-carnitine; morphometry. 